DEPÓSITO LEGAL ZU2020000153

Esta publicación científica en formato digital

es continuidad de la revista impresa

ISSN 0041-8811

E-ISSN 2665-0428

Revista

de la

Universidad

del Tunlia

Fundada en 1947

por el Dr. Jesús Emrique Lossada

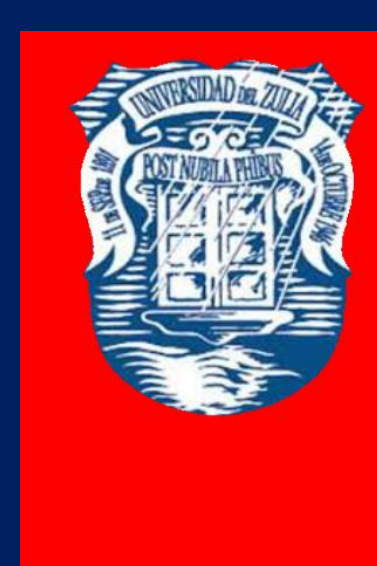

Ciencias

Sociales

y Arte

Aกัต 11 No 31

Septiembre - Diciembre 2021

Tercera ípoca

Maracailbo-Venezuela 
REVISTA DE LA UNIVERSIDAD DEL ZULIA. 3ª época. Año 11 N 31, 2020

Irina V. Andrusova et al. /// Health-saving technologies in teacher's activity, 461-472

DOI: http://dx.doi.org/10.46925//rdluz.31.29

\title{
Health-saving technologies in teacher's activity
}

\author{
Irina V. Andrusova * \\ Zhanna V. Smirnova** \\ Elena A. Chelnokova *** \\ Olga N. Nikeitseva ${ }^{* * * *}$ \\ Anna N. Tsaregorodtseva *****
}

ABSTRACT The state, society and the labor market are making ever higher demands on teaching staff. Compliance with the established requirements forces students to increase energy consumption, the rate of development of the data, which entails a violation of biological rhythms, poor health and poor performance. Therefore, there is a need to improve the competencies of teachers related to mastering ways to improve the functional state and human health. The relevance of health-saving technologies implementation in vocational education is growing. Since there is no special course for their study, additional training courses on this topic become popular. Purpose of the article: designing the content of the course for additional professional training of teaching staff, ensuring the achievement of the development of health-saving technologies and their use in professional training. The aim of the course is to promote development of the competencies of teaching staff in the field of health-saving technologies application. The article reveals the possibilities of health-saving technologies, the role in preparation of an efficient, highly qualified specialist who meets modern requirements and is able to carry out professional activities at a high level. The study, in which experts selected from among the teachers of a higher educational institution, contributed to the solution of the problem of selecting the content of the course of additional professional training. When selecting the course content, an expert opinion on the established criteria was taken into account. As the planned results of the course, we determined a list of competencies that ensure the ability and willingness of teachers to systematically implement health-saving technologies.

KEY WORDS: health- saving technologies, Listeners, optional course, professional education, students.

* Crimean Engineering and Pedagogical University the name of Fevzi Yakubov, Simferopol, Russia, ORCID: https:/orcid.org/0000-0002-0082-1373

* Minin Nizhny Novgorod State Pedagogical University, Uljanov street, 1, Nizhny Novgorod, Russia, ORCID: http://orcid.org/0000-0001-9950-9824

*** Minin Nizhny Novgorod State Pedagogical University, Uljanov street, 1, Nizhny Novgorod, Russia, ORCID: http://orcid.org/0000-0001-8673-6032

**** V.I. Vernadsky Crimean Federal University, Prospekt Vernadskogo 4, Simferopol, Russia, ORCID: https://orcid.org/0000-0001-8501-1304

***** Vyatka Social and Economic Institute, Kirov, Russia, ORCID: https://orcid.org/00000001-8873-6888

Recibido: 30/07/2020

Aceptado: 10/09/2020 
REVISTA DE LA UNIVERSIDAD DEL ZULIA. $3^{a}$ época. Año 11 N 31, 2020

Irina V. Andrusova et al. /// Health-saving technologies in teacher's activity, 461-472

DOI: http://dx.doi.org/10.46925//rdluz.31.29

\section{Tecnologías que promueven la salud en la actividad docente}

RESUMEN

El Estado, la sociedad y el mercado laboral plantean cada vez más exigencias al profesorado. El cumplimiento de los requisitos establecidos obliga a los estudiantes a incrementar el consumo de energía, el ritmo de desarrollo de los datos, lo que conlleva una violación de los ritmos biológicos, mala salud y bajo rendimiento. Por tanto, existe la necesidad de mejorar las competencias de los docentes relacionados con el dominio de formas de mejorar el estado funcional y la salud humana. La importancia de la implementación de tecnologías que promueven la salud en la educación profesional está aumentando. Dado que no hay un curso especial para su estudio, los cursos de capacitación adicionales sobre este tema se vuelven populares. Objeto del artículo: diseñar el contenido del curso para la formación profesional adicional del profesorado, asegurando el logro del desarrollo de tecnologías promotoras de la salud y su uso en la formación profesional. El objetivo del curso es promover el desarrollo de las competencias del profesorado en el campo de la aplicación de tecnologías que promueven la salud. El artículo revela las posibilidades de las tecnologías promotoras de la salud, el papel en la preparación de un especialista eficiente y altamente calificado que cumpla con los requisitos modernos y sea capaz de realizar actividades profesionales de alto nivel. El estudio, en el que expertos seleccionados entre los profesores de una institución de educación superior, contribuyó a la solución del problema de selección del contenido del curso de formación profesional adicional. Al seleccionar el contenido del curso se tuvo en cuenta la opinión de un experto sobre los criterios establecidos. Como resultados planificados del curso, determinamos una lista de competencias que aseguran la capacidad y disposición de los docentes para implementar sistemáticamente tecnologías promotoras de la salud.

PALABRAS CLAVE: tecnologías salvadoras de la salud, oyentes, curso opcional, educación profesional, estudiantes.

\section{Introduction}

To date, students have recorded many cases of functional disorders. The number of chronic diseases is growing, the proportion of diseases of the nervous, cardiovascular and digestive systems, musculoskeletal system is increasing. This trend is associated with an increase in the workload, the amount of information that needs to be mastered, constantly increasing requirements for student preparation, and lack of physical activity (Caputi et al., 2015). Fatigue, emotional and physical overload lead to interest decrease in professional courses development. Therefore, there is a need for appropriate measures. There is a need for the formation of the competencies of teachers related to a responsible and informed attitude 
REVISTA DE LA UNIVERSIDAD DEL ZULIA. $3^{a}$ época. Año 11 N 31, 2020

Irina V. Andrusova et al. /// Health-saving technologies in teacher's activity, 461-472

DOI: http://dx.doi.org/10.46925//rdluz.31.29

to health (Chertovskikh, 2019). To this end, conditions must be created aimed at a new system of values and models of health-saving behavior among modern students (Cirdan, 2019). Any educational technology implemented in the educational process should have a health-preserving character. In order for teachers to implement these technologies in their professional activities, appropriate training is required. As part of this training, we propose the introduction of an additional professional training course for teachers "Health-saving technologies in professional education", which will provide an opportunity to expand ideas about the implementation of health-saving technologies in the framework of professional activities (Vaganova, 2019a). These technologies will increase the attention, emotional mood, motivation of students (Brinson et al., 2015). Having mastered this course, students will be able to translate the knowledge gained in professional activities to students of secondary vocational schools, thereby maintaining their health and performance. The implementation of health-saving technologies helps educators build competencies related to the implementation of measures aimed at maintaining and improving their own health and the health of their students.

\section{Theoretical framework}

The issue of health conservation has attracted the attention of many scientific researchers for a long time. Today, along with the exacerbation of this problem, many new studies appear (Buranok et al., 2019). O.A. dealt with vocational training issues with an emphasis on the development of health-saving technologies. Akhverdova, S.N. Belova, I.V. Boev, O.V. Petrov and many other researchers are among them. One of the priority tasks of higher education institutions is the search for ways to preserve and strengthen the health of subjects of the educational process (Bulayeva et al., 2019). The works of scientists reflect the development of a health-saving orientation in the process of training teachers as an important component of the formation of professional competence (Vaganova et al., 2019b). Various aspects of health-saving technologies in teacher training are highlighted in the works of Yu.V. Naumenko, E.G. Dikanova, G.A. Novoselova. Many researchers highlight the concept of "health-saving pedagogy," which refers to a pedagogical system aimed at developing students' health awareness (Broadbent et al., 2015).

Health-saving pedagogy reveals new opportunities for students: 
REVISTA DE LA UNIVERSIDAD DEL ZULIA. $3^{a}$ época. Año 11 N 31, 2020

DOI: http://dx.doi.org/10.46925//rdluz.31.29

- the perception of the healing process not as a combination of preventive measures, but as a regular form of personality development and the process of expanding its psychophysiological capabilities, resistance to negative influences (Bespalko et al., 2017);

- the implementation of health-saving technologies is based on a personality-activity approach that allows the students to prepare for their personal characteristics (Chirva et al., 2018);

- the perception of a healthy person as an attainable norm of development (Raven, 2017).

Health-saving education includes the implementation of health-saving technologies (Tsarapkina et al., 2019a). These technologies, in turn, comprise a system of values and attitudes that form the students' need for increased motor activity, performing exercises to prevent impaired functioning of the musculoskeletal system (Andrienko et al., 2019a), blood circulation, breathing, and other processes. Researchers identify several types of healthsaving technologies in higher education:

- fitness activities;

- technologies related to life safety (Andrienko, 2019b);

- educational activities of the teaching staff (Denysenko, 2018).

The concept of health-saving technologies is interpreted by many researchers as a step-by-step process of implementing certain principles, educational methods and methods that complement educational technologies, endowing them with signs of health saving (Donetskova, 2019).

Health-saving technologies are manifested in:

- the rational organization of the educational process that meets sanitary standards and hygienic requirements (Petrichev et al., 2018);

- organization of dosed motor activity of students (Tsarapkina et al., 2019b);

- the formation of a value attitude to health.

Among hygienic means to achieve the goals of health-saving technologies, note:

- Fulfillment of sanitary and epidemiological requirements;

- personal and public hygiene (ventilation and wet cleaning) (Abramova et al., 2018);

- compliance with the regime of motor activity.

- limiting the level of the maximum academic load (Abramova et al., 2019). 
REVISTA DE LA UNIVERSIDAD DEL ZULIA. $3^{a}$ época. Año 11 N 31, 2020

Irina V. Andrusova et al. /// Health-saving technologies in teacher's activity, 461-472

DOI: http://dx.doi.org/10.46925//rdluz.31.29

\section{Methodology}

The article presents the development of the content of the course for additional professional training of teachers "Health-saving technologies in vocational education". The course is intended for teachers engaged in professional activities in the secondary vocational education system.

The study involved teachers of higher education. The teachers acted as experts for the selection of topics and technologies that should be included in the course of additional professional training of teachers

The generalized selection criteria for experts were:

- the level of expert competence in a given area;

- the validity of the expert opinion;

- Expertise's experience in the implementation of health saving technologies.

For the selection of experts, a mutual assessment method was used, in which expert tables were used. A group of specialists was formed, each of whom needed to indicate whom he considered a potential expert. The mutual assessment procedure was carried out in two stages. At the first, it was established how many times each participant was called an "expert" by another member of the group. At the second stage, based on the information received, a table was formed where the number of votes is considered as the "weight coefficient" of the expert. This method allowed ranking specialists by their expert qualities. Thus, 18 expert teachers were selected.

The selection of the content of the additional training course was carried out as follows. If this or that topic gained less than $50 \%$ of the vote, then it was not included in the list of recommended topics for inclusion in the course content.

\section{Results and discussion}

The holistic personality of a graduate capable of pursuing professional activities is one of the priority tasks of higher educational institutions. Competence, sustainable motivation and the need for self-improvement are necessary qualities of a modern teacher. However, due to negative trends in the dynamics of students' health indicators, among the important qualities of the teaching staff appears the ability to implement health-saving technologies. There is a need to improve the competencies of teachers related to health conservation. We propose the development and implementation of an additional professional training course 
REVISTA DE LA UNIVERSIDAD DEL ZULIA. $3^{a}$ época. Año 11 N 31, 2020

Irina V. Andrusova et al. /// Health-saving technologies in teacher's activity, 461-472

DOI: http://dx.doi.org/10.46925//rdluz.31.29

for teachers "Health-saving technologies", which will contribute to the rational implementation of professional activities that preserve the maximum performance of students in secondary vocational schools.

The purpose of the course: to promote the formation and development of competencies of teaching staff in the field of development and application of health-saving technologies.

The development and implementation of the course involves the following tasks:

- Theoretical training of students in the implementation of preventive activities to prevent diseases and maintain working capacity, development of skills in conducting the learning process using health-saving technologies;

- creating a health-saving educational environment;

- Attracting students to various research projects in the field of health promotion.

Course development is based on a systematic and integrative-differentiated approach.

A systematic approach to the implementation of the course allows you to:

- to form a holistic view of the students about the laws and laws of personality development, its training and the formation of competence;

- develop systematic thinking, move from reproductive learning to self-developing, and get away from simply transmitting information to students (a modern teacher should act as a consultant directing the student's activities, correcting his independent activity);

- to form the skill of building individual educational trajectories (in accordance with individual needs, the health characteristics of students);

- determine the relationship of behavioral reactions, creative abilities and biological processes.

The integrative-differential approach allows you to:

- combine various methods, tools and technologies for resolving specific situations in accordance with the individual characteristics and capabilities of students;

- follow the process of formation of competencies in dynamics;

- indicate the priority of the development of subject-subject relations between teacher and student.

To solve the problem of selecting the content of the course, we selected experts from among the teachers of the higher educational institution. The selection was carried out 
REVISTA DE LA UNIVERSIDAD DEL ZULIA. $3^{a}$ época. Año 11 N 31, 2020

Irina V. Andrusova et al. /// Health-saving technologies in teacher's activity, 461-472

DOI: http://dx.doi.org/10.46925//rdluz.31.29

within the educational institution, as these experts are more knowledgeable in many aspects of the research activities.

The generalized selection criteria for experts were:

- the level of expert competence in a given area;

- the validity of the expert opinion;

- Expertise's experience in the implementation of health saving technologies.

For the selection of experts, a mutual assessment method was used, in which expert tables were used. A group of specialists was formed, each of whom needed to indicate whom he considered a potential expert. The mutual assessment procedure was carried out in two stages. At the first, it was established how many times each participant was called an "expert" by another member of the group. At the second stage, based on the information received, a table was formed where the number of votes is considered as the "weight coefficient" of the expert. This method allowed ranking specialists by their expert qualities. Thus, 18 expert teachers were selected.

They were asked to choose the most significant topics of the course, as well as choose the most effective, in their opinion, technologies that contribute to the best development of the data.

Table 1 shows a list of topics proposed for evaluation by experts.

Table 1 . The content of the training course for additional professional training of teachers "Health-saving technologies in vocational education" selected by experts

\begin{tabular}{|l|l|}
\hline No & Curriculum Content Elements \\
\hline 1 & Health-saving technologies in vocational education: definition, classification \\
\hline 1 & Key research areas and concepts in the field of health-saving technologies \\
\hline 3 & $\begin{array}{l}\text { Medical and hygienic health-saving technologies. Sanitary and pedagogical } \\
\text { requirements for educational institutions }\end{array}$ \\
\hline 4 & Theoretical basis for developing an individual healthy lifestyle program \\
\hline 5 & Fitness technologies \\
\hline 6 & Environmental Health Technologies \\
\hline 7 & Life Safety Technologies \\
\hline 8 & A ichnostno-developing technology \\
\hline 9 & P eveloping zdorovesberega saving technologies in Russia and in the world \\
\hline 10 & With socially adaptive technologies \\
\hline
\end{tabular}


REVISTA DE LA UNIVERSIDAD DEL ZULIA. $3^{a}$ época. Año 11 N 31, 2020

Irina V. Andrusova et al. /// Health-saving technologies in teacher's activity, 461-472

DOI: http://dx.doi.org/10.46925//rdluz.31.29

The selection of content was carried out as follows. If this or that topic gained less than $50 \%$ of the vote, then it was not included in the list of recommended course content. When selecting the content, the experts took into account the interconnectedness of those with educational technologies that will be used in the implementation of the additional training course; the amount of time devoted to the study of a particular topic.

The results of processing the decision made by the experts are shown in Figure 1.\% percentage of experts who expressed a positive opinion on the inclusion of the topic in the course content. Each topic in the figure has its own number.

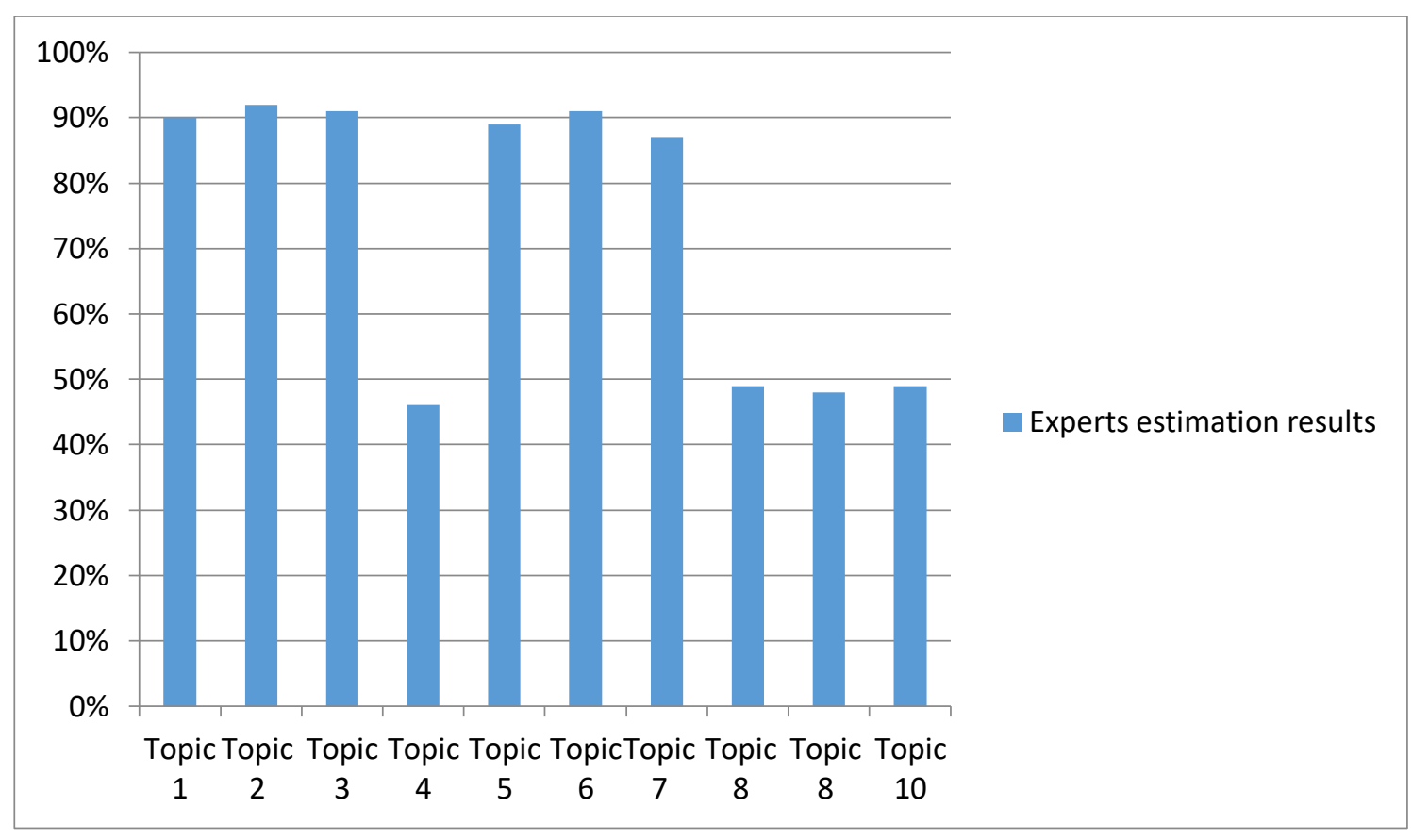

Fig. l. The results of statistical processing of data on the selection by experts of the content of the course of additional professional training of teachers (in the framework of our study)

Less than 50\% got topics No. 4, 8, 9, 10: "Personally-developing technologies", "Development of health-saving technologies in Russia and the world", "Socially adaptive technologies", "Theoretical foundations of developing an individual program of a healthy lifestyle". The most popular were 6 topics that are included in the content of the course "Health-saving technologies in vocational education".

The experts were also asked to select the most effective, in their opinion, educational technologies that will allow the course to be implemented. Among the technologies were proposed: gaming; design; differentiated learning; informational; interactive; your option. 
REVISTA DE LA UNIVERSIDAD DEL ZULIA. $3^{a}$ época. Año 11 N 31, 2020

Irina V. Andrusova et al. /// Health-saving technologies in teacher's activity, 461-472

DOI: http://dx.doi.org/10.46925//rdluz.31.29

In the process of conducting an expert assessment, teachers took into account the influence of a particular technology on the formation of competencies in the development and application of health-saving technologies. If a technology gains less than $50 \%$ of the vote, the technology is not included in the course implementation process.

Experts pointed out the importance of each of these technologies for the implementation of the course and the formation of relevant competencies.

In accordance with the requirements for the content, taking into account all types of activities, a curriculum-thematic plan was drawn up, including substantive sections, the distribution of the types of academic work, hours allocated to it and forms of final control. In the structure of the course, a lecture (10 lessons) and a practical part (8 lessons) were highlighted in which students will realize their theoretical and practical skills in using health-saving technologies.

Forms of conducting classes: lectures, (practical) design work, work in a distance learning format. In the classes, practical classes in small groups, discussions, cases, business games, projects will be implemented.

As the planned results of the implementation of the course, we determined the required list of competencies that ensure teachers' ability and readiness for the systematic implementation of health-saving technologies, readiness to ensure the safety of life and health of students, in particular, readiness for psychological and pedagogical support of the educational process, the ability to use rendering methods first aid.

As a result of mastering the course, the teacher should know the features of the health status of modern youth (students in secondary vocational schools); the specifics of the formation of motivation to maintain health, the principles of implementing health-saving technologies, to be able to use the methods of rationing the workload; take into account individual and age-related physiology of students, possess the skills of health-saving support of the learning process.

In order to determine the effectiveness of the course as a form of control, a written test was proposed on the theoretical aspects of the implementation of health-saving technologies, as well as project protection. 
REVISTA DE LA UNIVERSIDAD DEL ZULIA. $3^{a}$ época. Año 11 N 31, 2020

Irina V. Andrusova et al. /// Health-saving technologies in teacher's activity, 461-472

DOI: http://dx.doi.org/10.46925//rdluz.31.29

Conclusions

We have developed a course of additional professional training for teachers "Healthsaving technologies in vocational education", the content of which is determined by a group of experts from among the teachers of the higher educational institution. Through an expert assessment, 6 topics were identified. In the structure of the course, a lecture (10 lessons) and a practical part (8 lessons) were highlighted in which students will realize their theoretical and practical skills in using health-saving technologies. To implement the course, the experts selected the most effective technologies in their opinion. The expert assessment method allowed statistically substantiating the choice of topics and selecting the most effective educational technologies in the framework of the course. In order to determine the course effectiveness as a form of control, a written test was proposed on the theoretical aspects of the implementation of health-saving technologies, as well as project protection.

The implementation of the course will allow students to acquire competencies related to the process of health conservation, the implementation of health-saving technologies that they can apply in their professional activities, while maintaining the health and performance of students in secondary vocational schools.

\section{References}

Abramova, N.S., Vaganova, O.I., Kutepova, L.I. (2018) Development of educational and methodological support in the context of the implementation of information and communication technologies. Baltiyskiy gumanitarnyy zhurnal (Baltic Humanitarian Journal), 7, no. 2 (23), 181-184. (in Russ.).

Abramova, N.S., Vaganova, O.I., Smirnova Zh.V. (2019). Organization of independent work in the context of a practice-oriented approach, Azimut nauchnykh issledovaniy: pedagogika $i$ psikhologiya (Azimuth of Scientific Research: Pedagogy and Psychology).8, 1 (26). 13-15. (in Russ.).

Andrienko, O.A. (2019a). On the need to apply gaming training technologies. Balkan Scientific Review, 2 (4), 5-8.

Andrienko, O.A. (2019b). Modern educational technologies: technology of self-presentation. Balkan Scientific Review, 1(3), 5-7.

Bespalko, V. P. (2017). Cyberpedagogy is an educational challenge of the 21st century. Pedagogical technology of cyber pedagogy. School Technology, (1), 19-25. 
REVISTA DE LA UNIVERSIDAD DEL ZULIA. $3^{a}$ época. Año 11 N 31, 2020

Irina V. Andrusova et al. /// Health-saving technologies in teacher's activity, 461-472

DOI: http://dx.doi.org/10.46925//rdluz.31.29

Brinson, J. R. (2015). Learning outcome achievement in non-traditional (virtual and remote) versus traditional (hands-on) laboratories: A review of the empirical research. Computers o $~$ Education, 87, 218-237.

Broadbent, J., \& Poon, W. L. (2015). Self-regulated learning strategies \& academic achievement in online higher education learning environments: A systematic review. The Internet and Higher Education, 27, 1-13.

Bulayeva, M.N., Aleshugina, Ye.A., Maksimova, K.A. (2019). Modeling of the process of formation competence of teachers in university. Baltiyskiy gumanitarnyy zhurnal (Baltic Humanitarian Journal), 8, 3 (28), 21-24. (in Russ.).

Buranok, O. M., Timoshchuk, N. A. (2019). Improving the efficiency of the educational process of technical university through the integration of pedagogical technologies, Baltiyskiy gumanitarnyy zhurnal (Baltic Humanitarian Journal), 8, 2 (27), 106-109. (in Russ.).

Caputi, V., \& Garrido, A. (2015). Student-oriented planning of e-learning contents for Moodle. Journal of Network and Computer Applications, 53, 115-127.

Chertovskikh, O.O. (2019). Prospects for the use of digital resources in education. Baltiyskiy gumanitarnyy zhurnal (Baltic Humanitarian Journal). 8, 4 (29), 184-187. (in Russ.).

Chirva, A.N., Chirva, O.G. (2018). Contents and method of professionally oriented training of informatic courses of future teachers of technologies. Scientific Vector of the Balkans, 1, 27-31.

Cirdan, A.P. (2019). Innovative technologies of professional training of future economists in the system of continuous education. Humanitarian Balkan Research, 2(4), 27-30.

Denysenko, S.M. (2018). Application of quest technology in the professional training Of Bachelor of Publishing and Polygraphy in Higher School. Balkan Scientific Review, 1, 29-33.

Donetskova, O.YU. (2019). Modernization of the modern education system in Russia. Baltiyskiy gumanitarnyy zhurnal (Baltic Humanitarian Journal), 8, 2 (27), 37-39. (in Russ.).

Petrichev, P. V., Masyuk, N. N., Bushueva, M. A. (2018). Method of estimation of the effectiveness of the partnership russian universities with foreign educational organizations, Azimut nauchnykh issledovaniy (Azimuth of Scientific Researches: Economics and Management), 7,3 (24), 229-232.

Raven, J. (2017). Education and Sociocybernetics, Azimut nauchnykh issledovaniy (Azimuth of Scientific Researches: Economics and Management), 6, 3 (20), 289-297.

Tsarapkina, Ju. M., Dunaeva, N. V., Kireicheva, A. M. (2019b). Application of BYOD technology in education on the example of Lecture Racing mobile application, Informatika $i$ obrazovanie - Informatics and Education, 9 (308), 56-64. 
REVISTA DE LA UNIVERSIDAD DEL ZULIA. $3^{a}$ época. Año 11 N 31, 2020

Irina V. Andrusova et al. /// Health-saving technologies in teacher's activity, 461-472

DOI: http://dx.doi.org/10.46925//rdluz.31.29

Tsarapkina, Ju.M., Petrova, M.M., Mironov, A.G., Morozova, I.M., Shustova, O.B. (2019a). Robotics as a basis for Informatization of education in children's health camp. Amazonia Investiga, $8(20)$.

Vaganova, O. I. (2019a). Organization of practical classes in a higher educational institution using modern educational technologies. Amazonia Investiga, 8 (23), 81-86.

Vaganova, O.I., Odarich, I.N., Popkova, A.A., Smirnova, Z.V., Lebedeva, A.A. (2019b). Independent work of students in professional educational institutions. Amazonia Investiga, 8 (22), $295-304$. 